\title{
Economic Returns and Enhanced Quality in Orchid (Dendrobium Sonia 17) Using Biosafe Compound- Chitosan
}

\author{
Sunila Kumari*, Jitendra Singh and Panj FG \\ Department of Horticulture, Indira Gandhi Agricultural University, India
}

Submission: January 11, 2017; Published: April 28, 2017

"Corresponding author: Sunila Kumari, Department of Horticulture, Indira Gandhi Agricultural University, Centre for Agri-solutions and Technologies, TCL, Aligarh, India, Email: sunila.flora@gmail.com

\begin{abstract}
Increasing consumer demand and buoyant world market have promoted the status of orchid growing to an industry in our country which has led to higher focus on developing techniques to improve orchid quality and economics. Environment friendly inputs based on efficient use of natural resources are the need of present day planning, chitosan is one such compound. The present experiment was conducted under factorial completely randomized block design (Factorial CRD) with three factors replicated thrice at a net house to study the effect of chitosan foliar spray on orchid Dendrobium cv. Sonia. Results showed that chitosan significantly affected the yield, quality and thus the economics of orchid production. Chitosan treated plants yielded more number of spikes per meter square, greater spike length, increased internodal length, enhanced diameter of flower and more number of florets per spike. 7.5ppm chitosan chlorohydrate applied thrice yielded 100 percent A grade spikes. The economics calculated showed the highest benefit cost ratio (B:C) in 7.5ppm chitosan acetate applied four times and 7.5ppm chitosan acetate applied thrice (3.22 and 3.16, respectively). Apart from all these effects of chitosan, the chitosan treated plants showed lesser disease and pest infestation and also resulted in better overall appearance of spikes. Thus chitosan can play an important role in designing a sustainable production technology for orchids.
\end{abstract}

Keywords: Dendrobium; Chitosan; Biosafe; Quality improvement

\section{Introduction}

Orchids are accepted to be the world's most exotic and fascinating flowers, with extraordinary variety of sizes, shapes, colours and markings and are cosmopolitan occurring in almost all parts of world. The orchid cut flower industry is growing at an annual rate of $10-20 \%$ [1] and have immensely contributed to the economy of several developed and developing countries. With the increasing health consciousness and concern for environment, organic substitutes have drawn attention all over the world. Recently, role of Chitosan (a partially N-acetylated polymer of $\beta$-(1-4)-linked glucosamine) in improving production and quality of orchids has been indicated [2,3]. It is gaining popularity as it is environment friendly and bio degradable. Chitosan is yet to receive scientific evaluation in India. Hence the present study was undertaken to evaluate and standardize the chitosan application for quality improvements of orchids and make orchid cultivation more profitable by reducing cost of cultivation.

\section{Materials and Methods}

Present experiment was carried under partially controlled net house at Department of horticulture, Indira Gandhi Agricultural University, Raipur for two consecutive years during 2010-12. Two-year-old tissue culture plants of Dendrobiumcv. Sonia was used as experimental material. The experiment was laid in Factorial Completely Randomized Design with additional control, with total thirty-three treatment combinations. The treatment combinations consisted of two different formulations of chitosan (CP1 and CP2) at four different concentrations (C12.5ppm, C2-5ppm, C3-7.5ppm, C4-10 ppm) and four different number of applications (A1-one spray, A2-two spray, A3- three spray). Foliar application of chitosan was carried out until run off, using a manual sprayer, at monthly interval. Observation on various yield and quality parameters were taken and subjected to suitable statistical analysis. 
Results

Results showed that chitosan significantly affected the yield and quality parameters under study and improvement was recorded with all the treatments as compared to control. Also significant variation was observed among chitosan formulation, their concentrations and application frequencies. Data are presented in Table 1.

Table 1: Effect of chitosan foliar spray on yield and quality of Dendrobium cv. Sonia 17.

\begin{tabular}{|c|c|c|c|c|c|c|c|}
\hline Sn & Treatments & Spike Length & $\begin{array}{l}\text { No. Floret/ } \\
\text { Spike }\end{array}$ & $\begin{array}{c}\text { Spike } \\
\text { Diameter }\end{array}$ & $\begin{array}{c}\text { Internodal } \\
\text { Length }\end{array}$ & Vase Life & Yield / M.Sq. \\
\hline 1 & Control & 18.92 & 4.92 & 5 & 2.8 & 6.75 & 70.83 \\
\hline & \multicolumn{7}{|c|}{ Products } \\
\hline 2 & P1 & 27.92 & 6.45 & 6.28 & 3.18 & 10.34 & 144.05 \\
\hline \multirow[t]{4}{*}{3} & $\mathrm{P} 2$ & 30.78 & 7.48 & 6.97 & 3.14 & 9.73 & 124.64 \\
\hline & SE & 0.21 & 0.08 & 0.05 & 0.04 & 0.07 & 1.22 \\
\hline & C. D & 0.59 & 0.22 & 0.14 & 0.11 & 0.21 & 3.44 \\
\hline & \multicolumn{7}{|c|}{ Concentrations } \\
\hline 4 & $\mathrm{C} 1$ & 24.91 & 5.94 & 5.21 & 3.1 & 9.25 & 128.44 \\
\hline 5 & $\mathrm{C} 2$ & 30.03 & 6.74 & 6.36 & 3.31 & 10.21 & 142.81 \\
\hline 6 & C3 & 32.87 & 8.45 & 7.92 & 4.5 & 10.81 & 151.25 \\
\hline \multirow[t]{4}{*}{7} & $\mathrm{C} 4$ & 29.6 & 6.74 & 7 & 3.53 & 9.88 & 114.88 \\
\hline & S.E. & 0.3 & 0.11 & 0.07 & 0.05 & 0.1 & 1.72 \\
\hline & C. D & 0.83 & 0.31 & 0.2 & 0.15 & 0.3 & 4.87 \\
\hline & \multicolumn{7}{|c|}{ No. of Applications } \\
\hline 8 & $\mathrm{~A} 1$ & 28.5 & 6.7 & 6.36 & 3.47 & 9.75 & 129.54 \\
\hline 9 & A2 & 29.41 & 6.86 & 6.66 & 3.61 & 9.94 & 133.17 \\
\hline 10 & A3 & 30.23 & 7.11 & 6.9 & 3.75 & 10.17 & 139.27 \\
\hline \multirow[t]{3}{*}{11} & A4 & 29.26 & 7.19 & 6.6 & 3.62 & 10.29 & 135.4 \\
\hline & S.E. & 0.3 & 0.11 & 0.07 & 0.05 & 0.1 & 1.72 \\
\hline & C. D & 0.83 & NS & 0.2 & 0.15 & 0.3 & 4.87 \\
\hline \multirow[t]{5}{*}{12} & \multicolumn{7}{|c|}{ Control vs rest } \\
\hline & S.E. & 0.6 & 0.22 & 0.15 & 0.11 & 0.21 & 3.5 \\
\hline & C. D & 1.69 & 0.63 & 0.41 & 0.31 & 0.6 & 9.89 \\
\hline & \multicolumn{7}{|c|}{ Interactions } \\
\hline & & S.E. & S.E. & S.E. & S.E. & S.E. & S.E. \\
\hline 13 & $\mathrm{PXC}$ & 0.42 & 0.15 & 0.1 & 0.08 & 0.15 & 2.44 \\
\hline 14 & PXA & 0.42 & 0.15 & 0.1 & 0.08 & 0.15 & 2.44 \\
\hline 15 & $\mathrm{CXA}$ & 0.59 & 0.22 & 0.14 & 0.11 & 0.21 & 3.45 \\
\hline 16 & P XC XA & 0.83 & 0.31 & 0.2 & 0.15 & 0.3 & 4.88 \\
\hline & C.V.\% & 4.98 & 7.75 & 5.35 & 7.29 & 5.17 & 6.38 \\
\hline
\end{tabular}

Among the two chitosan formulations, chitosan acetate (P1) recorded, more number of flowers per meter square (144.05) and significantly longer vase life of spike (10.34 days) and more internodal length $(2.80 \mathrm{~cm})$. While, P2 recorded significantly longer spikes $(30.78 \mathrm{~cm})$, more florets per spike $(7.48)$ and more flower diameter $(6.97 \mathrm{~cm})$. Among all the chitosan concentrations applied, 7.5ppm (C3) was found to be beneficial for most characters and recorded maximum number of spike per plant (9.93), maximum number of spike per meter square (151.25), maximum spike length $(32.87 \mathrm{~cm})$, maximum number of floret per spike (8.45), maximum diameter of flower $(7.92 \mathrm{~cm})$, maximum internodal length $(4.5 \mathrm{~cm})$ and maximum vase life of spike (10.81 days). Three applications were found beneficial in most of the cases, and further more applications resulted in detrimental effects in most of the parameters under study. Three applications (A3) recorded maximum spike length $(30.23 \mathrm{~cm})$, maximum flowerdiameter $(6.90 \mathrm{~cm})$, maximum number of spike per plant (9.32) and maximum yield per m. sq. (139.27). Four applications (A4) recorded maximum vase life but they were at par with three applications (A3) (Table 2). 
Table 2: Cost ${ }^{\star}$ of production of Orchid (Dendrobium cv. Sonia) excluding Chitosan treatment.

\begin{tabular}{|c|c|}
\hline Details Of Area And Plant Population & 21860 \\
\hline Total no. of plants @16 pt per $\mathrm{m}^{2}(25 \mathrm{~cm} \times 25 \mathrm{~cm})$ & $=1366.2 \mathrm{~m} 2$ \\
\hline Total area of green house & cost $^{*}$ \\
\hline Grossed planted area & \\
\hline Items & 874400 \\
\hline A. Fixed cost & 80000 \\
\hline 1 Planting material @120per plant (3yrs life) & 15000 \\
\hline 2Net House @Rs. 1000per m $^{2}$ (life 25yrs) & 19388 \\
\hline 3 Shed net @ 30per msq (life 4 yrs) & 437200 \\
\hline 4 Repair and maintenance @2\% of total fixed cost & 32134.2 \\
\hline B. Cost of Cultivation & 43800 \\
\hline 5.Growing medium per plant @Rs 20/plant/year & 10262.684 \\
\hline R. Chemicals (like fertilizer, pesticides except chitosan treatments) @ & 1512184.884 \\
\hline 7 Labor (365 man days @ 20per day) & $1512184.884=$ Rs. 1512185 \\
\hline 8 Miscellaneous @2\% of cost of cultivation & \\
\hline Grand Total (A+B) & \\
\hline Total cost of production excluding Chitosan Treatment (X) & \\
\hline
\end{tabular}

The benefit to cost $(\mathrm{B}: \mathrm{C})$ ratio was highest in treatment combination P1C3A3 (7.5ppm chitosan acetate applied thrice) and P1C3A4 (7.5ppm chitosan acetate applied four times) and lowest in untreated control followed by P1C1A1 $(2.5 \mathrm{ppm}$ chitosan acetate applied once) (Table 3). Apart from all these

Table 3: Economics of chitosan treatments.

\begin{tabular}{|c|c|c|c|c|c|}
\hline \multirow[b]{2}{*}{ Treatment } & \multicolumn{2}{|c|}{ Cost of Cultivation } & \multirow[b]{2}{*}{ Gross Income } & \multirow[b]{2}{*}{ Net Return } & \multirow{2}{*}{$\begin{array}{c}\text { Cost Benefit Ratio } \\
\text { (CBR) }\end{array}$} \\
\hline & $\begin{array}{l}\text { Cost Of Chitosan } \\
\text { Treatment (Y) }\end{array}$ & Total $(\mathrm{X}+\mathrm{Y})$ & & & \\
\hline P1C1A1 & 11 & 1512196 & 3048334 & 1536138 & 1.02 \\
\hline P1C1A2 & 22 & 1512207 & 3256110 & 1743903 & 1.15 \\
\hline P1C1A3 & 33 & 1512218 & 3600506 & 2088289 & 1.38 \\
\hline P1C1A4 & 44 & 1512229 & 3665970 & 2153741 & 1.42 \\
\hline P1C2A1 & 22 & 1512207 & 3610943 & 2098736 & 1.39 \\
\hline $\mathrm{P} 1 \mathrm{C} 2 \mathrm{~A} 2$ & 44 & 1512229 & 3840540 & 2328311 & 1.54 \\
\hline P1C2A3 & 66 & 1512250 & 4612823 & 3100572 & 2.05 \\
\hline $\mathrm{P} 1 \mathrm{C} 2 \mathrm{~A} 4$ & 87 & 1512272 & 4764623 & 3252350 & 2.15 \\
\hline P1C3A1 & 33 & 1512218 & 5464800 & 3952582 & 2.61 \\
\hline P1C3A2 & 66 & 1512250 & 5382259 & 3870008 & 2.56 \\
\hline P1C3A3 & 98 & 1512283 & 6293059 & 4780775 & 3.16 \\
\hline P1C3A4 & 131 & 1512316 & 6386985 & 4874669 & 3.22 \\
\hline P1C4A1 & 44 & 1512229 & 3080212 & 1567983 & 1.04 \\
\hline $\mathrm{P} 1 \mathrm{C} 4 \mathrm{~A} 2$ & 87 & 1512272 & 3335426 & 1823153 & 1.21 \\
\hline $\mathrm{P} 1 \mathrm{C} 4 \mathrm{~A} 3$ & 131 & 1512316 & 3975263 & 2462946 & 1.63 \\
\hline $\mathrm{P} 1 \mathrm{C} 4 \mathrm{~A} 4$ & 175 & 1512360 & 3443393 & 1931033 & 1.28 \\
\hline $\mathrm{P} 2 \mathrm{C} 1 \mathrm{~A} 1$ & 6 & 1512191 & 2943023 & 1430831 & 0.95 \\
\hline $\mathrm{P} 2 \mathrm{C} 1 \mathrm{~A} 2$ & 12 & 1512197 & 3207724 & 1695527 & 1.12 \\
\hline P2C1A3 & 18 & 1512203 & 3557813 & 2045609 & 1.35 \\
\hline
\end{tabular}

effects of chitosan, the chitosan treated plants showed lesser mites infestation and also resulted in better overall appearance of spikes. disease and pest infestation, especially lesser leaf spots and 
Agricultural Research \& Technology: Open Access Journal

\begin{tabular}{|c|c|c|c|c|c|}
\hline $\mathrm{P} 2 \mathrm{C} 1 \mathrm{~A} 4$ & 25 & 1512209 & 4064445 & 2552236 & 1.69 \\
\hline $\mathrm{P} 2 \mathrm{C} 2 \mathrm{~A} 1$ & 12 & 1512197 & 4098600 & 2586403 & 1.71 \\
\hline $\mathrm{P} 2 \mathrm{C} 2 \mathrm{~A} 2$ & 25 & 1512209 & 4512255 & 3000046 & 1.98 \\
\hline $\mathrm{P} 2 \mathrm{C} 2 \mathrm{~A} 3$ & 37 & 1512222 & 4732365 & 3220143 & 2.13 \\
\hline $\mathrm{P} 2 \mathrm{C} 2 \mathrm{~A} 4$ & 49 & 1512234 & 4499921 & 2987687 & 1.98 \\
\hline P2C3A1 & 18 & 1512203 & 5165944 & 3653740 & 2.42 \\
\hline $\mathrm{P} 2 \mathrm{C} 3 \mathrm{~A} 2$ & 37 & 1512222 & 5612805 & 4100583 & 2.71 \\
\hline Р2С3A3 & 55 & 1512240 & 6147900 & 4635660 & 3.07 \\
\hline P2C3A4 & 74 & 1512258 & 5840505 & 4328247 & 2.86 \\
\hline P2C4A1 & 25 & 1512209 & 3441116 & 1928907 & 1.28 \\
\hline $\mathrm{P} 2 \mathrm{C} 4 \mathrm{~A} 2$ & 49 & 1512234 & 3375653 & 1863419 & 1.23 \\
\hline $\mathrm{P} 2 \mathrm{C} 4 \mathrm{~A} 3$ & 74 & 1512258 & 3256110 & 1743852 & 1.15 \\
\hline $\mathrm{P} 2 \mathrm{C} 4 \mathrm{~A} 4$ & 98 & 1512283 & 3109054 & 1596771 & 1.06 \\
\hline Control & 0 & 1512185 & 1532231 & 20046 & 0.01 \\
\hline
\end{tabular}

\section{Discussion}

Flower quality parameters decide the significance of a particular variety suitable for commercial cultivation and the value it fetches in market. In addition to number of florets, the compactness and arrangement of florets in spike are the other two characters which govern the price of spike. Length of internode of spike should be optimum for proper display of flowers, ample clearance between successive florets is essential to prevent overcrowding of florets whereas more clearance leads to the ungainly, prominent exposure of spike. The length of internode of spike was more in in P1 treated plants. Chitosan acetate (P1) and C3 (7.5ppm) recorded better vase life as compared to chitosan chlorohydrate (P2), which depends on spike length, flower diameter and number of florets per spike. Increase in vase life may be attributed to more photosynthates accumulated in chitosan treated plants. Similar results were reported by Chandrkrachang et al. [2]. Wanichpongpan et al. [4] had earlier reported that chitosan significantly enhanced growth factors in terms of the average values of flower-stem length as well as the number of flowers per bush in gerbera plants. In addition, chitosan may enhance growth and development by some signaling pathway related to auxin biosynthesis via a tryptophan-independent pathway [3]. In case of quality parameters, higher concentration of chitosan was found to be detrimental and best treatment (7.5ppm) was followed by $5 \mathrm{ppm}$ (C2) rather than 10ppm except in case of flower diameter which recorded an increase with increase in chitosan treatment. Similar results were reported by Tantasawat et al. [5], who reported no stimulatory effect of chitosan at higher concentrations. In the present study P1 produced more number of spikes per plant and also higher yield per meter square. The increased flower yield might be attributed to enhanced accumulation of photosynthates due to chitosan application [6,7].

Since Dendrobium orchid cultivation is an upcoming business opportunity especially in tropical belts of India, it is essential to work out economics. In the present study chitosan application was found to be beneficial in increasing the profits. Similarly, Walkar et al. [8] found that the profit at different cost levels was maximum in case of orchid and the input-output ratio worked out to be 1: 1.30 in orchid. The economics is directly related to yield, thus the present results in economics may be attributed to higher spike yield per plant and per meter square area.

Thus present study proves Dendrobium cv. Sonia as a rewarding commercial crop, where cost of chemical can be reduced and quality can be significantly improved using chitosan application. These results are in accordance with that of Nagare \& Pal [9]. Thus, chitosan is not only pollution safe, but nourishes the plant and less costly too Delphine et al. [10].

\section{Acknowledgment}

This research was supported by ICAR, New Delhi in the form of PGS-SRF. The author thanks Multan Industries, Gujarat for supplying Chitosan in kind.

\section{References}

1. Winrock International (2002) Animal agriculture in Sub Saharan Africa. University of California, Davis, In-stitute of Agricultural Development, USA.

2. Bime MJ, Fouda TM, Mai Bong JR (2014) Analysis of the Profitability and Marketing Channels of Rice: A Case Study of Menchum River Valley, North-West Region, Cameroon. Asian Journal of Agriculture and Rural Development 4(6): 352-360.

3. Programme Nationale de Vulgarisation et de Recherche Agricole (PNVRA) (2002) Preparation of the farming season 2002. PNVRA in flash, PNVRA / NAERP/NWP, Bamenda, Cameroon.

4. Milling III (2009) National Strategy for Rice Growing in Cameroon. p. 7.

5. Djomo CRF (2015) Analysis of Technical Efficiency and Profitability in Small Scale rice Production in the West Region of Cameroon. University of Agriculture, Makurdi-Benue State, Nigeria.

6. Food and Agriculture Organization of the United Nations (FAO) (2006) Brief on Import Surges, Countries, $\mathrm{n}^{\circ} 4$, Cameroon: Poultry, Rice and Vegetable Oils. Commodities and Trade division, Rome, Italy, p. 20. 
7. Piebeb G (2008) Evaluating the Constraints and Opportunity for sustainable Rice Production in Cameroon. Research Journal of Agriculture and Biological Sciences 4(6): 734-744.

8. Yerima BPK, Van RE (2005) Soils of Cameroon, distribution, genesis, characteristics, management and utilization. Edition clef, Yaoundé, Cameroon, pp. 52-54.
9. Freedman DA (2009) Cambridge university press, India, p. 26

10. International Rice Research Institute (IRRI) (2013) Nourishing a nation. Rice Today 12: 9.

11. Tibshirani R (1996) Regression Shrinkage and Selection via the Lasso. Journal of the Royal Statistical Society Series B 58(1): 267-288.

\section{Your next submission with Juniper Publishers} will reach you the below assets

- Quality Editorial service

- Swift Peer Review

- Reprints availability

- E-prints Service

- Manuscript Podcast for convenient understanding

- Global attainment for your research

- Manuscript accessibility in different formats

( Pdf, E-pub, Full Text, Audio)

- Unceasing customer service

Track the below URL for one-step submission https://juniperpublishers.com/online-submission.php 